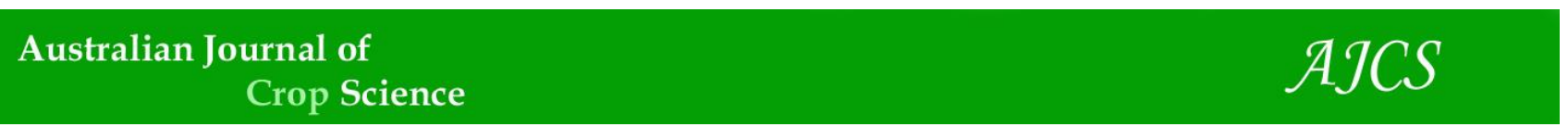

AJCS 14(06):1004-1010 (2020)

ISSN:1835-2707

doi: 10.21475/ajcs.20.14.06.p2524

\title{
Strategy of nitrogen fertilizer application to increase growth and yield of rice in ratoon system at tidal swampland
}

\author{
Gribaldi Gribaldi ${ }^{*}$, Nurlaili Nurlaili, Firnawati Sakalena, Nurmala Dewi, Ardi Asroh \\ Departemen of Agrotecnology, Faculty of Agriculture, University of Baturaja, Jl. RatuPenghulu No. 02301 \\ Karang Sari Baturaja 32115, South Sumatra, Indonesia
}

\section{"Correspondence: gribaldi64@yahoo.co.id}

\section{Abstract}

This study aims to determine the effect of regulating the provision of nitrogen fertilizer on several rice varieties on the growth and yield of rice in ratoon system at the Tidal swampland. A split plot design was employed in this experiment. The main plot was nitrogen fertilizer application (N) consisting of N1, N2, N3, and N4. The subplot is rice varieties (V) consisting of Inpari 30 (V1), Inpara 3 (V2), Inpari 33 (V3), Inpari 43 (V4) and Hipa 5 Ceva (V5). The results showed that $1 / 2$ dose nitrogen fertilization given at planting $+1 / 2$ dose at primordia had a good effect on the growth and yield of the main crop, whereas $1 / 3$ dose nitrogen fertilization given at planting $+1 / 3$ dose at primordia $+1 / 3$ dose at harvest tends to have a good effect on ratoon yield. Variety Hipa 5 Ceva produced highest yield of unhusked rice (i.e. 4.9 tons ha ${ }^{-1}$ for the main crop and 2.71 tons ha ${ }^{-1}$ for ratoon) at (N3): $135 \mathrm{~kg} \mathrm{~N} \mathrm{ha}^{-1}$ fertilizer, when $1 / 2$ dose was given at planting $+1 / 2$ dose at primordia. The variety Hipa 5 Ceva with various nitrogen fertilization strategies provided the highest total grain yield in the ratoon system at tidal swampland.

Keywords: nitrogen fertilizing, ratoon system, rice variety, tidal swampland.

Abbreviations: N1_fertilizing with $1 / 2$ dose at planting $+1 / 2$ dose at primordia phase with dose of $90 \mathrm{~kg} \mathrm{~N}^{-1}$; N2_fertilizing with $1 / 3$ dose at planting $+{ }^{1} / 3$ dose at primordia phase $+1 / 3$ dose at harvest, at dose of $90 \mathrm{~kg} \mathrm{~N} \mathrm{ha}^{-1}$; N3_fertilizing of $1 / 2$ dose at planting $+1 / 2$ dose at primordia phase, at dose of $135 \mathrm{~kg} \mathrm{~N} \mathrm{ha}^{-1}$; N4_fertilizing of $1 / 3$ dose at planting $+1 / 3$ dose at primordia phase $+{ }^{1} / 3$ dose at harvest, at dose of $135 \mathrm{~kg} \mathrm{~N} \mathrm{ha}^{-1}$; DAP_day after planting.

\section{Introduction}

Tidal swampland is suboptimal land have potential to be developed for rice cultivation. Area of tidal swampland in Indonesia is estimated of about 20.1 million hectares and about 9.53 million hectares have potential to be developed for agricultural purposes (Haryono, 2013).

Rice production at tidal swampland area is still low, estimated about 600-700 thousand tons of milling dry unhull rice per year or about 1.5 percent from national rice production of 62.56 million tons of milling dry unhull rice at productivity level of 3.0-5.0 ton ha ${ }^{-1}$. This low level of rice productivity among others is caused by land biophysical condition and environment as well as cultivation system (BBSDLP, 2011). Therefore, one of the efforts to increase rice productivity in tidal swampland is through ratoon rice cultivation.

Ratoon is a rice plant that grows again to produce new tillers and can produce harvestable grain (Islam et al., 2008). Apart from providing additional production, it also saves production inputs, costs, labor and preparation time for planting (Santos et al., 2003). In ratoon, the harvest time is $40 \%$ shorter, water savings are as much as $60 \%$, savings in production inputs are as much as $38 \%$ and production can reach $50 \%$ of the main crop (Oad et al., 2002). The use of varieties and appropriate fertilization is the key to success in the ratoon system of rice cultivation in tidal swampland.

According to Gribaldi and Nurlaili (2019), the use of proper variety, which is suitable to specific environment will have effect on rice growth and yield at tidal swampland. Generally, tidal swampland farmers in southern Sumatra use plant rice varieties of inhibrida, such as inpari 30, with productivity ranging from 2.7-3.0 tons $\mathrm{ha}^{-1}$ (Suparwoto and Waluyo, 2019). This productivity is far lower than the national rice productivity, which is 3.0-5.0 tons ha $^{-1}$ (BBSDLP, 2011). Efforts to increase production continues to be encouraged. One of them is by planting hybrid rice. Planting of hybrid rice is one of efforts to utilize technology in increasing rice production. According to Zuanita and Suryanto (2018), hybrid rice has potential of 20-30 percent higher than that of inbred rice variety. Susilawati et al. (2011) stated that hybrid rice had better growth than inbred rice variety and produced higher harvest dry unhull rice per hectare with magnitude of about 39 percent. Moreover, studies conducted by Gribaldi and Nurlaili (2019) showed that the use of hybrid rice variety of Hipa 5 Ceva was capable to increase rice production with magnitude of about 16 to 36 percent than that of inbred rice variety. Innovation of nitrogen fertilizer application is also needed in addition to proper rice variety usage. In addition to the use of varieties, 
proper fertilization is also needed through the provision of nitrogen fertilizer.

Nitrogen $(\mathrm{N})$ is essential nutrient and plants require higher $\mathrm{N}$ than other nutrients, besides it is a limiting factor for plant productivity (Duan et al., 2007). Therefore, $\mathrm{N}$ fertilizer application is highly needed to increase rice growth and rice yield. According to Fifi (2016), application of $\mathrm{N}$ fertilizers at dose of $138 \mathrm{~kg} \mathrm{ha}^{-1}$, is equivalent to urea fertilizer at dose of $300 \mathrm{~kg} \mathrm{ha}^{-1}$. This has produced the highest growth and yield of ratoon rice, although the recommended dose of nitrogen fertilizer for rice crop is $92 \mathrm{~kg} \mathrm{ha}^{-1}$ or equivalent to urea fertilizer at dose of $200 \mathrm{~kg} \mathrm{ha}^{-1}$ (Ambarita, 2018). According to Sakakibara et al. (2006), nitrogen has significant effect on rice tillers development. In addition, Alfandi (2006) stated that application of half dose $\mathrm{N}$ fertilizer at planting time will affect vegetative phase growth of crop, especially plant height and tillers development. The study was conducted by Gribaldi et al. (2013) showed that application of half dose urea fertilizer at planting time $+\mathrm{Si}$ and $\mathrm{Zn}$ nutrients produced the highest yield of unhulled rice in all tested varieties, while the rest was applied 42 days after planting (DAP).

This study aims to determine the effect of regulating the provision of nitrogen fertilizer on several rice varieties on the growth and yield of rice in the ratoon system at the Tidal swampland.

\section{Results}

Results of analysis of variance in Table 1 showed that variety type (V) had significant effect on all variables both in the main crop and ratoon, whereas $\mathrm{N}$ fertilization had significant effect on parameters such as 100 grains weight, numbers of grains per panicle, percentage of filled grains, grain yield of ratoon which had significant effect. Interaction between varieties and fertilizing treatments showed no significant effect, except for parameters of numbers of grains per panicle and percentage of filled grains per panicle.

\section{The chemical property of soil prior to treatment}

Analysis results of soil chemical properties prior to treatment at experimental land plot showed very low soil fertility, acid soil $\mathrm{pH}(\mathrm{pH}=4.63)$ with high Al-dd content (Table 2). Base content such as $\mathrm{Ca}, \mathrm{Mg}$ and $\mathrm{K}$-dd was in the range of low, indicating low nutrients availability at experimental land. Ameliorant in form of manure fertilizer at dose of 10 ton $\mathrm{ha}^{-1}$ and nitrogen fertilizer were added to improve soil fertility so that lacking of nutrients availability could be overcome and could increase rice plant production.

\section{Number of tillers main crop}

Strategy of $\mathrm{N}$ fertilizing application for several rice varieties at age of 42 days after planting (DAP) in relation to number of tillers main crops at tidal swampland area can be seen in Table 3. The results showed that number of tillers for Hipa 5 Ceva variety was not significantly different than Inpari 43 variety, but it was significantly different than other varieties. Hipa 5 Ceva variety is hybrid variety that has more tillers than that of inbred varieties (Inpari 30, Inpara 3, Inpari 33 and Inpari43) with magnitude of 13.8 tillers plant $^{-1}$.

\section{Plant dry matter weight main crop}

Table 4. shows the effect of $\mathrm{N}$ fertilizing strategies on several rice varieties in relation to plant dry matter weight of main crops at age of 42 days after planting (DAP) at tidal swampland area. The results of this study showed that plants dry matter weight at age of 42 days after planting was significantly different amongst varieties, in which hybrid variety of Hipa 5 Ceva had the highest dry matter weight with magnitude of $20.1 \mathrm{~g}$ plant $^{-1}$.

\section{Yield and yield components in main crop}

The effect of varieties and fertilizing treatments at tidal swampland area on grain yield (ton $\mathrm{ha}^{-1}$ ) can be observed in Table 1. The varieties treatment had significant effect on grain rice yield, in which hybrid variety of Hipa 5 Ceva was significantly different from the other inbred varieties (Table 5). The hybrid variety Hipa 5 Ceva showed the highest grain yield ( 4.9 tons ha 1 ), when $1 / 2$ dose of fertilizer was applied at planting time and the rest at primordia phase with total dose of $135 \mathrm{~kg} \mathrm{~N} \mathrm{ha}^{-1}$. The main crop yield component for the treatment of nitrogen fertilizer in several rice varieties was significantly different in the amount of grain per panicle and percentage of filled grain (Table 6). The Hipa 5 Ceva variety showed the highest number of grains and the percentage of unfilled grain in some nitrogen fertilizer treatments.

\section{Yield ratoon crop}

The regulation of nitrogen fertilizer application on several rice varieties influences the grain yield in ratoon (Table 1). Nitrogen fertilizers when applied at $1 / 3$ dose at harvest + $1 / 3$ dose at primordia $+1 / 3$ dose at harvest $(N 2, N 4)$ tends to show higher grain yield compared to other treatments. Hipa 5 Ceva varieties are significantly different from other treatments of grain yield in ratoons. The highest grain yield in ratoon, which is 2.7 tons $\mathrm{ha}^{-1}$ was obtained from the treatment of Hipa 5 Ceva varieties given nitrogen dose of $135 \mathrm{~kg} \mathrm{ha}^{-1}$, with the administration of $1 / 3$ dose at harvest + $1 / 3$ dose at primordia $+1 / 3$ dosage at harvest (Table 7). Hipa 5 Ceva varieties with various nitrogen fertilization strategies produce the highest total unhusked rice, which is 6.9 tons $\mathrm{ha}^{-1}$ with a ratoon system in tidal swampland (Fig. 1)

\section{Discussion}

\section{Effect of fertilization on the growth of main crop}

Plants in growth and production stage optimally require the availability of nutrient elements in sufficient quantities in the soil, which one of the important one is nitrogen fertilization. In addition to the dose, the time of administration/application will determine the success of fertilization. According to Tando (2018), inaccurate application of fertilizer causes plants to not be able to grow and produce optimally. The results of analysis of various nitrogen fertilization strategies in several rice varieties affect the growth of rice plants. This was observed in number of tillers and dry weight of plants (Table 1). The treatment of Hipa 5 Ceva varieties was significantly different from the treatment of other varieties affecting the dry weight of the main crops 42 day after planting (DAP) (Table 4). 
Table 1. Analysis of variance results in term of nitrogen fertilizing effect on the observed parameter of rice varieties.

\begin{tabular}{|c|c|c|c|c|}
\hline No & The observed parameters & $\begin{array}{l}\text { Variety } \\
\text { (V) }\end{array}$ & Fertilizing $(\mathrm{N})$ & $\begin{array}{l}\text { Interaction } \\
\text { (I) }\end{array}$ \\
\hline 1 & $\begin{array}{l}\text { Number of Tillers main crop per clump } \\
\text { (tiller) }\end{array}$ & $3.37^{*}$ & $1.92 \mathrm{~ns}$ & $1.92 \mathrm{~ns}$ \\
\hline 2 & $\begin{array}{l}\text { Plant dry matter weight main crop per } \\
\text { clump (g) }\end{array}$ & $4.67^{*}$ & $1.82 \mathrm{~ns}$ & $0.37 \mathrm{~ns}$ \\
\hline 3 & 100 grains weight main crop $(\mathrm{g})$ & $5.01 *$ & $14.71 *$ & $1.50 \mathrm{~ns}$ \\
\hline 4 & Numbers of grains main crop per panicle & $55.72 *$ & $9.39 *$ & $5.79 *$ \\
\hline 5 & $\begin{array}{l}\text { Percentage of filled grains main crop per } \\
\text { panicle }(\%)\end{array}$ & $13.76 *$ & $6.03 *$ & $8.97^{*}$ \\
\hline 6 & Grain yield main crop per hectare (ton) & $6.96 *$ & $0.54 \mathrm{~ns}$ & $1.44 \mathrm{~ns}$ \\
\hline 7 & Grain yield ratoon crop per hectare (ton) & $7.49 *$ & $36.11 *$ & $1.23 \mathrm{~ns}$ \\
\hline
\end{tabular}

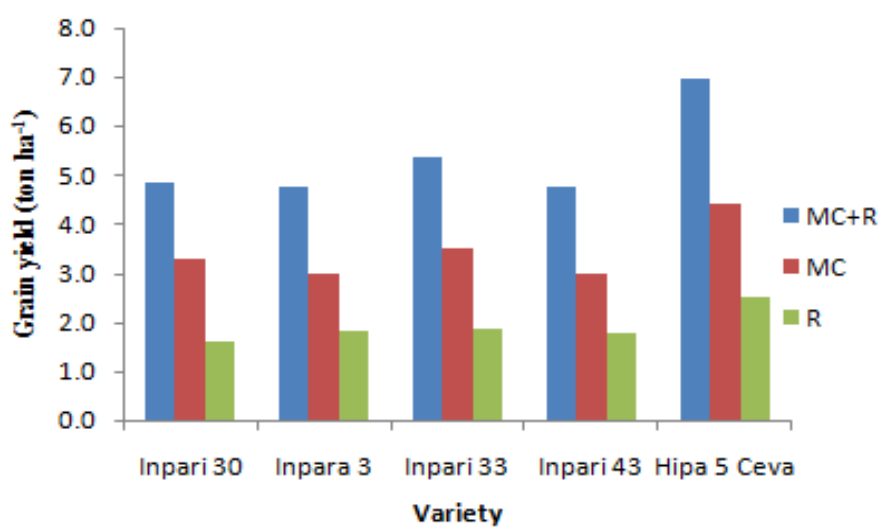

Fig 1. Grain yield (ton ha ${ }^{-1}$ ) ratoon (R), main crop (MC), main crop + ratoon (MC+R) of several rice varieties related to $\mathrm{N}$ fertilizing in system ratoon at tidal swampland area.

Table 2. Analysis results of several soil characteristics prior to treatment.

\begin{tabular}{llll}
\hline Soil Properties & Unit & Value & ${ }^{*}$ Criteria \\
\hline $\mathrm{pH}\left(\mathrm{H}_{2} \mathrm{O}\right) 1: 1$ & - & 4.63 & Acid \\
Organic-C & $\mathrm{g} \mathrm{kg}^{-1}$ & 3.29 & High \\
Total-N & $\mathrm{g} \mathrm{kg}^{-1}$ & 0.25 & Medium \\
Available-P & $\mathrm{ppm}$ & 27 & High \\
Exchangable-K & $\mathrm{cmol}(+) \mathrm{kg}^{-1}$ & 0.13 & Low \\
Exchangable-Na & $\mathrm{cmol}(+) \mathrm{kg}^{-1}$ & 0.33 & Low \\
Exchangable-Ca & $\mathrm{cmol}(+) \mathrm{kg}^{-1}$ & 0.70 & Low \\
Exchangable-Mg & $\mathrm{cmol}(+) \mathrm{kg}^{-1}$ & 0.22 & Very Low \\
CEC & $\mathrm{cmol}(+) \mathrm{kg}^{-1}$ & 15.23 & Low \\
Exchangable-Al & $\mathrm{cmol}(+) \mathrm{kg}^{-1}$ & 2.10 & High \\
Texture & $\%$ & & \\
Sand & $\%$ & 41.94 & \\
Loam & $\%$ & 24.08 & \\
Clay & $\%$ & 33.98 &
\end{tabular}

Source: Soil Science Laboratory, Agricultural Faculty, Sriwijaya University, South Sumatera, Indonesia, 2019. *The criteria proposed by Balai Penelitian Tanah (2005).

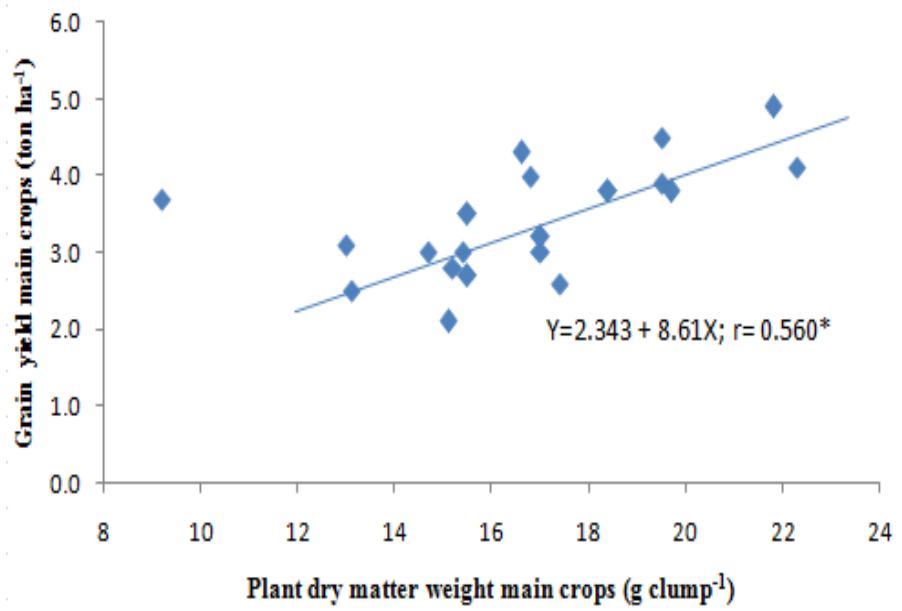

Fig 2. Relationship between plant dry matter weight and grain yield of main crop at tidal swampland area. 
Table 3. Number of tillers in main crop (tiller clump ${ }^{-1}$ ) at age of 42 days after planting (DAP) on several rice varieties and fertilizing treatments at tidal swampland area.

\begin{tabular}{|c|c|c|c|c|c|c|}
\hline \multirow{2}{*}{$\begin{array}{l}\text { Treatment } \\
\text { Fertilizing } \\
\text { (N) }\end{array}$} & \multicolumn{5}{|c|}{ Varieties (V) } & \multirow[t]{2}{*}{$\mathrm{N}$ average (Tukey. $.05: 5.07$ ) } \\
\hline & $\begin{array}{l}\text { Inpari } \\
30\end{array}$ & $\begin{array}{l}\text { Inpara } \\
3\end{array}$ & $\begin{array}{l}\text { Inpari } \\
33\end{array}$ & Inpari 43 & Hipa 5 Ceva & \\
\hline N1 & 12.1 & 11.6 & 12.6 & 14.8 & 14.9 & 13.1 \\
\hline N2 & 10.0 & 11.5 & 11.3 & 12.3 & 14.1 & 11.8 \\
\hline N3 & 10.2 & 12,0 & 11.1 & 11.4 & 12.7 & 11.5 \\
\hline N4 & 11.8 & 10.9 & 13.1 & 12.1 & 13.8 & 12.3 \\
\hline$V$ average (Tukey.05:2.7) & 11.0a* & $11.5 \mathrm{a}$ & $12.0 \mathrm{a}$ & $12.6 \mathrm{a}$ & $13.9 \mathrm{~b}$ & \\
\hline
\end{tabular}

* Means followed by the same letters at the same row are not significantly different based on Tukey test at $P \leq 0.05 . \mathrm{N} 1=$ fertilizing of $1 / 2$ dose at planting $+1 / 2$ dose at primordia phase at dose of 90 $\mathrm{kg} \mathrm{N} \mathrm{ha}^{-1} ; \mathrm{N} 2=1 / 3$ dose at planting $+1 / 3$ dose at primordia phase $+1 / 3$ dose at harvest at dose of $90 \mathrm{~kg} \mathrm{~N} \mathrm{ha}^{-1}$ and N3 $=1 / 2$ dose at planting $+1 / 2$ dose at primordia phase at dose of $135 \mathrm{~kg} \mathrm{~N}^{-1} ; \mathrm{N} 4=$ $1 / 3$ dose at planting $+1 / 3$ dose at primordia phase $+1 / 3$ dose at harvest at dose of $135 \mathrm{~kg} \mathrm{~N} \mathrm{ha}^{-1}$.

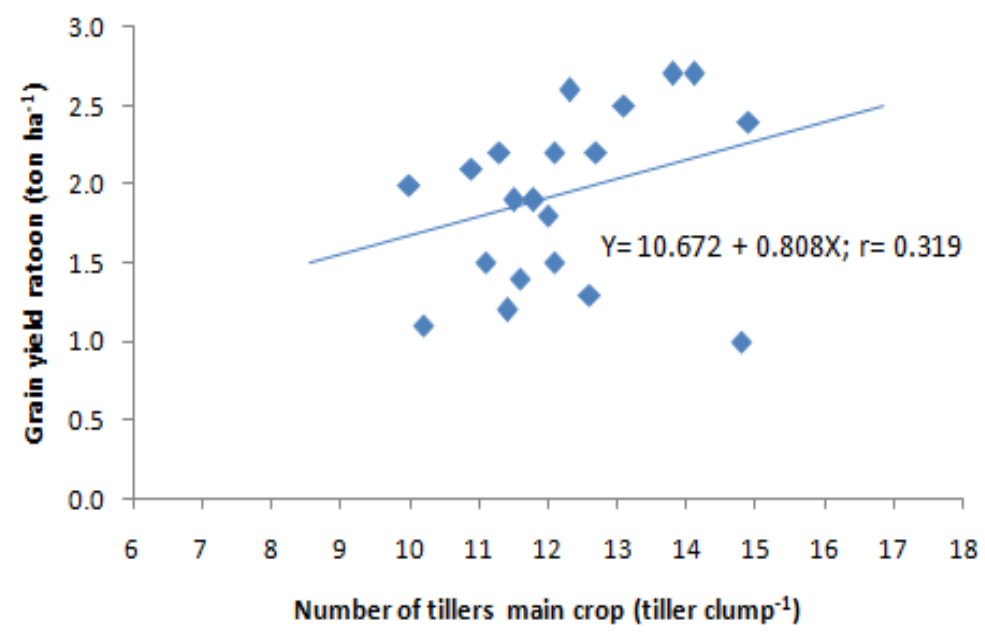

Fig 3. Relationship between number of tillers in main crop and grain yield of ratoon at tidal swampland area.

Table 4. Plant dry matter weight main crop $\left(\mathrm{g} \mathrm{clump}^{-1}\right.$ ) at age of 42 days after planting (DAP) on several rice varieties and fertilizing treatments at tidal swampland area.

\begin{tabular}{|c|c|c|c|c|c|c|}
\hline Treatment & & & Varieti & & & $\mathrm{N}$ average (Tukey. $.05: 8.6$ ) \\
\hline Fertilizing & Inpari & Inpara & Inpari & Inpari 43 & Hipa 5 Ceva & \\
\hline$(\mathrm{N})$ & 30 & 3 & 33 & & & \\
\hline N1 & 18.4 & 15.5 & 16.8 & 15.1 & 22.3 & 17.7 \\
\hline N2 & 15.2 & 13.1 & 15.4 & 9.2 & 16.6 & 13.9 \\
\hline N3 & 19.7 & 15.5 & 19.5 & 17.0 & 21.8 & 18.6 \\
\hline N4 & 17.4 & 17.0 & 14.7 & 13.0 & 19.5 & 16.3 \\
\hline V average (Tukey ${ }_{.05}: 6.4$ ) & $17.7 a^{*}$ & $15.3 \mathrm{a}$ & $16.6 \mathrm{a}$ & $13.6 \mathrm{a}$ & $20.1 \mathrm{~b}$ & \\
\hline
\end{tabular}

* Means followed by the same letters at the same row are not significantly different based on Tukey test at $P \leq 0.05$. N1 = fertilizing of $1 / 2$ dose at planting $+1 / 2$ dose at primordia phase at dose of $90 \mathrm{~kg} \mathrm{~N} \mathrm{ha}^{-1} ; \mathrm{N} 2=1 / 3$ dose at planting $+1 / 3$ dose at primordia phase $+1 / 3$ dose at harvest at dose of $90 \mathrm{~kg} \mathrm{~N}$ ha ${ }^{-1}$ and N3 $=1 / 2$ dose at planting $+1 / 2$ dose at primordia phase at dose of $135 \mathrm{~kg} \mathrm{~N} \mathrm{ha}^{-1} ; \mathrm{N} 4=1 / 3$ dose at planting $+1 / 3$ dose at primordia phase $+1 / 3$ dose at harvest at dose of $135 \mathrm{~kg} \mathrm{~N}^{-1}$.

Table 5. Grain yield main crop (ton $\mathrm{ha}^{-1}$ ) of several rice varieties and fertilizing treatments at tidal swampland area.

\begin{tabular}{|c|c|c|c|c|c|c|c|}
\hline \multirow{2}{*}{$\begin{array}{l}\text { Treatment } \\
\text { Fertilizing } \\
\text { (N) }\end{array}$} & \multicolumn{6}{|c|}{ Varieties (V) } & \multirow{2}{*}{$\begin{array}{l}\mathrm{N} \text { average } \\
\text { (Tukey.05: } \\
1.62 \text { ) }\end{array}$} \\
\hline & $\begin{array}{l}\text { Inpari } \\
30\end{array}$ & $\begin{array}{l}\text { Inpara } \\
3\end{array}$ & $\begin{array}{l}\text { Inpari } \\
33\end{array}$ & Inpari 43 & $\begin{array}{l}\text { Hipa } \\
\text { Ceva }\end{array}$ & 5 & \\
\hline N1 & 3.8 & 3.5 & 4.0 & 2.1 & 4.1 & & 3.5 \\
\hline N2 & 2.8 & 2.5 & 3.0 & 3.7 & 4.3 & & 3.3 \\
\hline N3 & 3.8 & 2.7 & 3.9 & 3.0 & 4.9 & & 3.7 \\
\hline N4 & 2.6 & 3.2 & 3.0 & 3.1 & 4.5 & & 3.3 \\
\hline
\end{tabular}

* Means followed by the same letters at the same row are not significantly different based on Tukey test at $P \leq 0.05$. N1 = fertilizing of $1 / 2$ dose at planting $+1 / 2$ dose at primordia phase at dose of $90 \mathrm{~kg} \mathrm{~N} \mathrm{ha}^{-1} ; \mathrm{N} 2=1 / 3$ dose at planting $+1 / 3$ dose at primordia phase $+1 / 3$ dose at harvest at dose of $90 \mathrm{~kg} \mathrm{~N}$ ha ${ }^{-1}$ and N3 $=1 / 2$ dose at planting $+1 / 2$ dose at primordia phase at dose of $135 \mathrm{~kg} \mathrm{~N} \mathrm{ha}^{-1} ; \mathrm{N} 4=1 / 3$ dose at planting $+1 / 3$ dose at primordia phase $+1 / 3$ dose at harvest at dose of $135 \mathrm{~kg} \mathrm{~N}^{-1}$. 
Table 6. The effect of fertilizing and rice variety on several rice yield components main crop at tidal swampland area.

\begin{tabular}{llll}
\hline Treatment & \multicolumn{2}{l}{ Yield component } & 3 \\
\cline { 2 - 4 } & 1 & 2 & $29 \mathrm{~b}-\mathrm{d}$ \\
\hline N1V1 & $93 \mathrm{de}$ & $90 \mathrm{c}-\mathrm{e}$ & 2.6 \\
N1V2 & $91 \mathrm{~cd}$ & $90 \mathrm{c}-\mathrm{e}$ & 2.6 \\
N1V3 & $85 \mathrm{bc}$ & $95 \mathrm{fg}$ & 2.3 \\
N1V4 & $63 \mathrm{a}$ & $92 \mathrm{c}-\mathrm{g}$ & 2.5 \\
N1V5 & $116 \mathrm{gh}$ & $93 \mathrm{~d}-\mathrm{g}$ & 2.4 \\
N2V1 & $80 \mathrm{bc}$ & $92 \mathrm{c}-\mathrm{g}$ & 2.3 \\
N2V2 & $92 \mathrm{de}$ & $88 \mathrm{bc}$ & 2.0 \\
N2V3 & $60 \mathrm{a}$ & $85 \mathrm{~b}$ & 1.9 \\
N2V4 & $64 \mathrm{a}$ & $94 \mathrm{e}-\mathrm{g}$ & 2.3 \\
N2V5 & $99 \mathrm{ef}$ & $94 \mathrm{e}-\mathrm{g}$ & 2.5 \\
N3V1 & $103 \mathrm{fg}$ & $94 \mathrm{e}-\mathrm{g}$ & 2.8 \\
N3V2 & $105 \mathrm{fg}$ & $91 \mathrm{c}-\mathrm{f}$ & 2.5 \\
N3V3 & $103 \mathrm{fg}$ & $76 \mathrm{a}$ & 2.6 \\
N3V4 & $62 \mathrm{a}$ & $92 \mathrm{c}-\mathrm{e}$ & 2.5 \\
N3V5 & $125 \mathrm{~h}$ & $94 \mathrm{c}-\mathrm{e}$ & 2.9 \\
N4V1 & $105 \mathrm{fg}$ & $93 \mathrm{c}-\mathrm{e}$ & 2.5 \\
N4V2 & $98 \mathrm{ef}$ & $94 \mathrm{c}-\mathrm{e}$ & 2.4 \\
N4V3 & $73 \mathrm{ab}$ & $92 \mathrm{c}-\mathrm{e}$ & 2.3 \\
N4V4 & $85 \mathrm{bc}$ & $96 \mathrm{~g}$ & 2.3 \\
N4V5 & $107 \mathrm{fg}$ &
\end{tabular}

1. Number of grains per panicle (Tukey.os=13.61), 2. Percentage of filled grains (\%) (Tukey. $\left.{ }_{05}=4.08\right)$ and 3. 100 grains weight $(\mathrm{g}) .{ }^{*}$ Means followed by the same letters within columns of each treatment and measured trait are not significantly different based on Tukey test at $P \leq 0.05$. V1: Inpari 30, V2: Inpara 3, V3: Inpari 33, V4: Inpari 43, V5: Hipa 5 Ceva. N1 = fertilizing of $1 / 2$ dose at planting $+1 / 2$ dose at primordia phase; $N 2=1 / 3$ dose at planting $+1 / 3$ dose at primordia phase $+1 / 3$ dose at harvest, each at dose of $90 \mathrm{~kg} \mathrm{~N}$ ha ${ }^{-1}$ and N3 $=1 / 2$ dose at planting $+1 / 2$ dose at primordia phase; $\mathrm{N} 4=1 / 3$ dose at planting $+1 / 3$ dose at primordia phase $+1 / 3$ dose at harvest, each at dose of $135 \mathrm{~kg} \mathrm{~N} \mathrm{ha}^{-1}$.

Table 7. Grain yield ratoon crop (ton $\mathrm{ha}^{-1}$ ) of several rice varieties and fertilizing treatments at tidal swampland area.

\begin{tabular}{|c|c|c|c|c|c|c|c|}
\hline \multirow{3}{*}{$\begin{array}{l}\text { Treatment } \\
\text { Fertilizing } \\
\text { (N) }\end{array}$} & \multicolumn{6}{|c|}{ Varieties (V) } & \multirow[t]{3}{*}{$\mathrm{N}$ average (Tukey $\left.{ }_{.05}: 1.60\right)$} \\
\hline & Inpari & Inpara & Inpari & Inpari 43 & Hipa & 5 & \\
\hline & 30 & 3 & 33 & & Ceva & & \\
\hline N1 & 1.45 & 1.39 & 1.33 & 1.01 & 2.38 & & 1.51 \\
\hline N2 & 2.01 & 1.88 & 2.15 & 2.61 & 2.69 & & 2.27 \\
\hline N3 & 1.07 & 1.78 & 1.49 & 1.24 & 2.20 & & 1.56 \\
\hline N4 & 1.91 & 2.14 & 2.52 & 2.23 & 2.71 & & 2.30 \\
\hline V average (Tukey.05: 0.63 ) & $1.61 a^{*}$ & $1.80 \mathrm{a}$ & $1.87 \mathrm{a}$ & 1.77 & $2.50 \mathrm{~b}$ & & \\
\hline
\end{tabular}

* Means followed by the same letters at the same row are not significantly different based on Tukey test at $P \leq 0.05 . \quad \mathrm{N} 1=$ fertilizing of $1 / 2$ dose at planting $+1 / 2$ dose at primordia phase at dose of 90 $\mathrm{kg} \mathrm{N} \mathrm{ha}^{-1} ; \mathrm{N} 2=1 / 3$ dose at planting $+1 / 3$ dose at primordia phase $+1 / 3$ dose at harvest at dose of $90 \mathrm{~kg} \mathrm{~N} \mathrm{ha}^{-1}$ and $\mathrm{N} 3=1 / 2$ dose at planting $+1 / 2$ dose at primordia phase at dose of $135 \mathrm{~kg} \mathrm{~N} \mathrm{ha}^{-1} ; \mathrm{N} 4=$ $1 / 3$ dose at planting $+1 / 3$ dose at primordia phase $+1 / 3$ dose at harvest at dose of $135 \mathrm{~kg} \mathrm{~N} \mathrm{ha}^{-1}$.

The high yield of this variety compared to other varieties is caused by the high number of tillers (Table 3). So, it also affects the dry weight of plants.

According to Mungara (2013), the increase of plants dry matter weight is an indicator of the increase of plants growth and development. According to Suryaningrum et al. (2016), plant dry matter weight is an accumulation of organic compounds that has been successfully been synthesized by plant from inorganic compounds, especially water and carbohydrate.

The high number of tillers in the Hipa 5 Ceva hybrid variety is suspected to be more adaptive to environmental conditions with low pH soils, namely $\mathrm{pH} 4.6$ (Table 2 ). So, the vegetative growth is faster than other varieties. This was in accordance with Virmani and Kumar (2004), which stated that hybrid rice had high adaptation capability in low $\mathrm{pH}$ environment. According to Husna (2010), tiller numbers of rice plant would be maximum if it has suitable genetic characteristics and suitable environmental condition for its growth and development. In addition, Satoto et al. (2009) had stated that hybrid rice has higher vigor than inbred rice and genetic property of hybrid rice is superior compared to its parents. Therefore, hybrid rice has better vegetative growth (Susilawati et al., 2011).
The treatment strategy of nitrogen fertilization has no effect on the growth of the main crop at 42 day after planting (DAP). But there is a tendency to administer $1 / 2$ dose nitrogen fertilizer given at planting and $1 / 2$ more doses given at primordia, both at $90 \mathrm{~kg} \mathrm{~N} \mathrm{ha}^{-1}$ or $135 \mathrm{~kg} \mathrm{~N} \mathrm{ha}^{-1}(\mathrm{~N} 1, \mathrm{~N} 3)$ producing a higher dry weight of the plant compared to other treatments (Table 4). It is suspected that in this treatment, the availability of nitrogen is sufficient for plant growth up to 42 day after planting (DAP). According to Siregar and Marzuki (2011), timely application of nitrogen fertilizer, which is adjusted to the development of plants, will increase the efficient use of nitrogen fertilizer. Furthermore, according to Suwignyo et al. (2008), regulation of fertilizer application especially nitrogen would have effect on plant height and plant dry matter weight.

\section{Effect of fertilization on grain yield of main crop and ratoon}

The results of the diversity analysis showed that the fertilizing strategy of several rice varieties affected grain yield, both for the main crop and ratoon in tidal swampland (Table 1). The Hipa 5 Ceva varietiy showed significantly different from other varieties to produce grain yield in both the main crop and ratoon, each producing the highest grain, 
which is 4.4 tons $\mathrm{ha}^{-1}$ for the main crop and 2.5 tons ha ${ }^{-1}$ for ratoon (Table 5 and Table 7 ). The high grain yield obtained in the main crop because it showed a good growth. This can be seen from the high dry weight variables obtained in this variety (Table 4). According to Mungara (2013), the increase of plants dry matter weight is an indicator of the increase of plants growth and development. The dry weight of the main crop has a strong relationship in determining the yield of the main crop grain. The pattern of relationship of dry weight of the main crop to the main crop grain yield based on polynomials was positive liner, ie $Y=2,343+8.61 X ; r=$ 0.560* (Fig. 2). As the dry weight of the plant increases, the grain yield will significantly increase as well. In addition, Hipa 5 Ceva (V5) produced the highest amount of grain per panicle in the main crop in various nitrogen fertilization strategies (Table 6). The high number of grains per panicle obtained in the main crop will affect the yield of grain per hectare in the main crop. According to Khairullah (2006), yield component per clump is one of the determinants of yield potential in rice plants. The high grain yield was observed in ratoons of Hipa 5 Ceva variety. This variety also has a large number of tillers, namely 13.9 tillers (Table 3 ). The high number of tillers is expected to produce many ratoon shoots as well. This can be seen from the pattern of the relationship of the number of main crop tillers to the grain yield in ratoon based on positive linear polynomials, namely $Y=10,672+0.81 X ; r=0.319$ (Fig. 3). By increasing the number of main crop tillers, the grain yield will increase as well, although the increase is not statistically significant ( $r$ $\leq 0.5$ ). It is believed that the grain yield in ratoon is not only determined by the number of main crop tillers, but also there are several other factors determining the grain yield in ratoon. According to Liu et. al. (2015), grain yield in ratoons is determined among others by variety, planting time, fertilization rate and cutting height of main stems. Moreover, Islam et. al. (2008) mentioned that fertilizer applied on main crop and ratoon could supply nutrients for ratoon. In general, the results of this study (Table 5 and Table 7), showed application of (N1 and N2): $1 / 2$ dose of nitrogen fertilizer at planting $+1 / 2$ dose at primordia showed a high reduction in grain yield in the main crop. The nitrogen fertilization $1 / 3$ dose at planting $+1 / 3$ dose at primordia $+1 / 3$ dose at harvest of the main crop showed a high reduction in grain yield in ratoon crops, both at a dose of $90 \mathrm{~kg} \mathrm{~N} \mathrm{ha}^{-1}$ or at a dose of $135 \mathrm{~kg} \mathrm{~N} \mathrm{ha}^{-1}$. The accumulation of grain yield obtained through the highest ratoon system was obtained in the treatment of Hipa 5 Ceva varieties at the $\mathrm{N}$ does of $1 / 3$ at planting $+1 / 3$ dose at primordia $+1 / 3$ dose at harvest of the main crop. These treatments produced 6.9 tons ha $^{-1}$ per planting season (Fig. 3) or grain yield increases of 59 percent compared to the main crop. The high grain yield of ratoon has been widely reported by researchers before. Nair and Rossama (2002) and Santos et al. (2003) reported that additional yields from ratoon could reach 66 percent, compared to main crops per planting season.

\section{Materials and Method}

\section{Plant material and seedling preparation}

Four inbred varieties and one hybrid variety were used in this study. Inpari 30 variety is a variety commonly grown by tidal swampland farmers. Rice seeds of varietas Inpari 30, Inpara 3, Inpari 33, Inpari 43, dan Hipa 5 Ceva varieties were incubated for 3 days and after germinatoin was seeded on raised beds with size of $1.2 \times 8 \mathrm{~m}$.

\section{Field experiment}

This study was conducted from April to July 2019 at Experimental Site of Agricultural Agency of Banyuasin District, Telang Sari Village, Tanjung Lago Subdistrict, Banyuasin District, South Sumatra, Indonesia. The soil texture in this study was sandy clay loam with $41.94 \%$ sand, $24.08 \%$ loam and $33.98 \%$ clay (Table 2 ), while the land used in this study was tidal swampland, which is located in the area around the coast marked by the direct effect of runoff from the ebb and flow of sea water.

\section{Experimental design and procedures}

Split Plot Design was employed in this experiment. The main plot is nitrogen fertilizer application $(N)$ in the main crop consisting of $\mathrm{N} 1=$ fertilization with $90 \mathrm{~kg} \mathrm{~N} \mathrm{ha}^{-1}$ when $1 / 2$ dose applied at planting $+1 / 2$ dose at primordia phase at dose. N2 $=90 \mathrm{~kg} \mathrm{~N} \mathrm{ha}^{-1}$ when $1 / 3$ dose applied at planting $+1 / 3$ dose at primordia phase $+1 / 3$ dose at harvest. N3 $=135 \mathrm{~kg} \mathrm{~N} \mathrm{ha}^{-1}$ when $1 / 2$ dose applied at planting $+1 / 2$ dose at primordia phase. N4 $=135 \mathrm{~kg} \mathrm{~N} \mathrm{ha}^{-1}$ when $1 / 3$ dose applied at planting + $1 / 3$ dose applied at primordia phase $+1 / 3$ dose at harvest. The subplot was the rice varieties $(\mathrm{V})$ consisting of $\mathrm{V} 1=$ Inpari 30, V2= Inpara 3, V3= Inpari 33, V4= Inpari 43 and V5 = Hipa 5 Ceva. Each treatment combination was replicated three times. The 21-day-old seeds were transferred into each experimental plot (unit) with size of $3 \times 2 \mathrm{~m}$. A 10 ton ha 1 of manure was previously added to the plots. Subsequently, seeds were planted at vertical position with planting distance of $25 \times 25 \mathrm{~cm}$ and using two seeds per planting hole with depth of $2 \mathrm{~cm}$ according to method of Gribaldi et al. (2016). N fertilizing was given according to the treatments. Fertilization with $90 \mathrm{~kg} \mathrm{~N} \mathrm{ha}^{-1}$ when $1 / 2$ dose applies at planting $+1 / 2$ dose at primordia is a common method being used by tidal swampland farmers.

The $\mathrm{P}$ and $\mathrm{K}$ fertilizers were given on all treatments at planting time with dose of $60 \mathrm{~kg} \mathrm{ha}^{-1}$, respectively (Setiawan et al., 2012). Grain yield from ratoon is obtained by cutting the main crop stem with a height of $15-20 \mathrm{~cm}$ from the soil surface (Nakano et al., 2009). We allowed plants to grow until the harvest. The shoots that were emerge from the former main crop cutting are called ratoon (Susilawati et al., 2018). Harvest of the main and ratoon crops are done when the grains in yellow panicles reached 80 percent. The accumulation of main crop yields and ratoon crop yields is the result of rice cultivation in the ratoon system.

\section{Parameters measured}

Parameters measured were clustered into: (1) number of Tillers main crop per clump (tiller); (2) plant dry matter weight main crop per clump (g). (3) numbers of grains main crop per panicle (grains); (4) percentage of filled grains main crop per panicle (\%);(5) 100 grains weight main crop (g), (6) grain yield main crop per hectare (ton) and (7) grain yield ratoon crop per hectare (ton).

\section{Statistical analysis}

Agronomic characteristics data was analyzed statistically using Analysis of Variance (ANOVA) followed by Tukey test at $P \leq 0.05$. All data calculation was done by SPSS 22.0 program and data was presented in form of tables and figures. 


\section{Conclusion}

Nitrogen fertilization with $1 / 2$ dose given at planting $+1 / 2$ dose at primordial stage tended to have a good effect on the growth and yield of the main crop, whereas nitrogen fertilization of $1 / 3$ dose given at planting $+1 / 3$ dose at primordia $+1 / 3$ dose at harvest tends to have a good effect on ratoon yield. The Hipa 5 Ceva reached the highest yield of unhusked rice, (i.e. 4.9 tons $\mathrm{ha}^{-1}$ for the main crop and 2.71 tons ha ${ }^{-1}$ for ratoon) at $135 \mathrm{~kg} \mathrm{~N} \mathrm{ha}^{-1}$ fertilizer when $1 / 2$ dose nitrogen fertilization is given at planting $+1 / 2$ dose at primordia. The nitrogen fertilization strategy of $1 / 3$ dose at planting $+1 / 3$ dose at primordia $+1 / 3$ dose at harvest is also recommended. The Hipa 5 Ceva variety produced the highest total grain yield under various nitrogen fertilization strategies, which was 6.9 tons $\mathrm{ha}^{-1}$ in a ratoon system at tidal swampland.

\section{Acknowledgements}

The acknowledgement is delivered to Ministry of Research, Technology and Higher Education that had already provided funding for this research through Applied Grant of 2019 with contract number: T/140/E3/RA.00/2019.

\section{References}

Alfandi (2006) The effect of cutting height (ratoon) and $\mathrm{N}$ fertilizer on rice production (Oryza sativa L.) of ciherang cultivar. J Agrijati. 2(1): 1-7.

Ambarita Y, Hariyono D, Aini N (2018) Application of NPK and urea fertilizers on rice (Oryza sativa L.) using ratoon system. J Crop Prod. 5:1228-1234.

BBSDLP (2011) State of the art and grand design for swampland development. Center of agricultural land resource, Bogor. 44p. (in Indonesian)

Duan YH, Zhang YL, Ye LY, Fan XR, Xu GH, Shen QR (2007) Responses of rice cultivars with different nitrogen use efficiency to partial nitrate nutrition. Ann Bot. P.1153-1160.

Fifi M (2016) The effect of nitrogen fertilizer application on the growth and yield of paddy field rice ratoon (Oryza sativa L.). http://scholar.unand.ac.id/id/eprint/19366.html, Accessed on 28 July 2019.

Gribaldi, Suwignyo RA, Hasmeda M, Hayati R (2013) Setting of nitrogen fertilizer application to increase tolerance and recovery of rice crop against flooding stress. J Subopt Land. 2(2): 151-158.

Gribaldi, Suwignyo RA, Hasmeda M, Hayati R (2016) Fertilization strategy to increase rice growth and production under two flooding condition on two swamp lowland types. Int J Agrivita. 38(1): 64-72.

Gribaldi, Nurlaili (2019) Growth response and yield of several rice varieties at tidal swampland area. J Chl. 5(1): 47 -52.

Haryono (2013) Strategi and policies of the agricultural ministry in suboptimal land optimization to support national food security. In: Herlinda S, Lakitan B, Sobir, Koesnandar, Suwandi, Puspitahati, Syafutri MI, Meidalima D. (eds.). The National seminar of suboptimal land proceedings, University of Sriwijaya, Palembang. 20-21 September 2013
Husna Y (2010) The Effect of planting distance on the growth and production of paddy field rice (Oryza sativa L.) of IR 42 variety using SRI method (System of Rice Intensification). J Sagu. 9(1): 2-

Islam MS, Hasannuzzaman M, Rukonuzzaman MD (2008) Ratoon rice response to different fertilizer doses in irrigated condition. J Agric Conspec Sci. 73:197-202.

Khairullah I (2006) Flooding resistant rice (solution of harvesting failure during flooding). Sinar Tani. Edition 8-14 Nopember, 2006.

Liu K, Li Y, Hu H (2015) Predicting ratoon rice growth rhythmbased on NDVI at key growth stages of main rice. Chilean J Agric Res. 75(5):410-417

Mungara E, Indradewa D, Rogomulyo R (2013) Analysis of growth and yield of paddy field rice (Oryza sativa L.) on conventional agricultural system, organic transition and organic. Vegatalika. 2(3): 1-12.

Nair AS, Rosamma CA (2002) Character association in ratoon crop of rice (Oryza sativa L.). J Tropic Agric. 40(2): 1-3

Nakano H, Morita S, Kitagawa H, Takahashi M (2009) Effect of cutting height and trampling over stubbles of the first crop on dry matter yield in twice harvest of forage rice. Plant Prod Sci. 12: 124-127.

Oad FC, Cruz PS (2002) Rice varietal screening for ratoon ability Pakistan J Appl Sci. 2:114-119.

Santos AB, Fageria NK, Prabhu AS (2003) Rice ratooning management practices for higher yields. Commun Soil Sci Plant Anal. 34:881-918.

Satoto, Sutaryo B, Suprihatno B (2009) Development prospect of hybrid rice variety. http://bbpadi.litbang.pertanian.go.id/index.php/publikasi/ artikelilmiah/prospek-pengembangan-varietas-padi-hibrida.html, Accessed on 12 December 2010.

Sakakibara H, Takey K, Hirose (2006) Interaction between nitrogen and cytokinin in the regulation of metabolism and development. Trends Plant Sci. 11: 440-448.

Setiawan A, Moenandir J, Nugroho H (2012) The Effect of N, P and $\mathrm{K}$ fertilizingon rice growth and yield (Oryza sativa L.) Kepras. http://

pustakapertanianub.staff.ub.ac.id/files/2012/05/JURNAL.pdf.html , Accessed on 1 April 2015

Siregar A, Marzuki I (2011) Efficiency of urea fertilization on N uptake and increase in paddy rice plants production (Oryza sativa L). J Budidaya Pertanian. 7(2):107-112.

Suparwoto, Waluyo (2019) Cultivition and adaptation of new superior varieties paddy in lebak swampland in South Sumatra. J Litbang Pertanian. 38(1): 13-22

Susilawati, Purwoko BS, Aswiddinnor H, Santoso E (2011) Perfomance of new rice varieties and strains in Indonesia on ratoon system. J Agron Indo. 38 (3): 177-184.

Susilawati, Purwoko BS (2018) The ability of hybrid and inbred rice to produce ratoon in Tidal swampland. Indo J Agric Sci. 19(2): 83 89.

Suryaningrum R, Purwanto E, Sumiyati (2016) Growth analysis of several soybean varieties a different drought stress intensities. J Agrosains. 18(2): 33- 37.

Tando E (2018) Efficiency efforts and enhancement of nitrogen availability in the soil and nitrogen uptake in lowland rice plants (Oryza sativa L). Buana Sains. 18(2): 171-180.

Virmani SS, Kumar I (2004) Development and use of hybrid rice technology to increase rice productivity in the tropics. IRRN. 29(1): 10-20

Zuanita R, Suryanto A (2018) Efforts to increase crop yield of inbred and hybrid rice (Oryza sativa L.) by regulating planting system. J Crop Prod. 6: 1913 -1922. 